\title{
Tähendusläbirääkimised ja vestlust toetavad strateegiad algajate eesti keele õppijate ja emakeele- kõnelejate interaktsioonis
}

\author{
RAILI POOL \\ Tartu Ülikool
}

Ülevaade. Artikkel on esimene osa algajate eesti keele õppijate ja emakeelekõnelejate suulist interaktsiooni käsitlevast pikiuuringust. Informantideks on viis täiskasvanud keeleõppijat (emakeeled inglise, rumeenia, udmurdi ja vene), kes õppisid eesti keelt intensiivkursusel. Uurimuses osales ka kolm eesti keelt emakeelena kõnelejat, kes olid õppijate vestluspartneriteks. Kõigil emakeelekõnelejatel oli eesti keele kui teise keele õpetamise kogemus. Nelja informandiga on aastase perioodi jooksul salvestatud neli, ühe informandiga kaks vestlust emakeelekõnelejaga, vestluste keskmine pikkus on 20 minutit. Käesoleva artikli ainestik pärineb esimestest lindistustest, mille tegemise hetkel olid informandid viibinud Eestis 6-7 nädalat ja õppinud eesti keelt umbes 100 akadeemilist tundi. Artikli keskmes on tähendusläbirääkimised ehk need suhtluse etapid, kus vestlejatel tekib vajadus mingeid problemaatilisi väljendeid eraldi seletada. Materjali analüüs näitab, et arusaamisprobleem tekkis enamasti keeleõppijatel, kelle strateegiaks probleemist märkuandmisel oli peamiselt paus või abiotsimine mõnes muus mõlemale vestlejale ühises keeles. Emakeelekõnelejatel õppijate lausungite mõistmisel probleeme peaaegu ei tekkinud, rohkesti kasutati õppijaid toetavaid suhtlusstrateegiaid (kordamine, öeldu parafraseerimine, sobivate väljendite pakkumine, tõlkimine). Suhtluse õnnestumisele aitas kaasa ka informantide 
vestluspartnerite varasem eesti keele kui teise keele õpetamise kogemus ning muude ühiste keelte kasutamine suhtluse käigus.

Võtmesõnad: eesti keel teise keelena; teise keele omandamine; interaktsioonianalüüs; tähendusläbirääkimised; suhtlusstrateegiad; õpetajakõne; eesti keel

\section{Sissejuhatus}

Teise keele omandamise üks keskseid uurimissuundi on keeleõppijate suuline suhtlus ning alaga tegelejad on nüüdseks üksmeelel selles, et õpitava keele kasutamine suulises kommunikatsioonis aitab keeleomandamisele kaasa. Käesolev artikkel käsitleb algajate eesti keele õppijate ja eesti keelt emakeelena kõnelejate suulist interaktsiooni, keskendudes tähendusläbirääkimistele ning nende käigus rakendatavale suhtlusstrateegiatele. Interaktsiooni all mõistetakse keele kasutamist kommunikatiivsel eesmärgil, rõhuga pigem tähendusel kui korrektsusel (Philp \& Tognini 2009: 246). Tähendusläbirääkimised ja suhtlusstrateegiad kuuluvad ka emakeelekõnelejate omavahelisse interaktsiooni ja teise keele kõnelejate omavahelisse suhtlusse nii keeletunnis kui tavavestluses, samuti õpetaja ja õppijate vahelisse suhtlusse keeletunni käigus. Siinses artiklis vaadeldakse algajate eesti keele õppijate ja emakeelekõnelejate vaba suulist suhtlust. Uuritavate vestluste eripära seisneb selles, et kõigil vestlustesse kaasatud emakeelekõnelejatel on eesti keele kui teise keele õpetamise kogemus, kuid vestlustes osalejatel puudus õpetaja ja õpilase suhe. Tegemist ei ole niisiis keeleõppesituatsiooniga, vaid vestluses osalejatele on püütud luua võimalikult pingevaba ja ilma kindlate ülesanneteta suhtlusolukord.

Tähendusläbirääkimisteks (ingl negotiation of meaning) nimetatakse suhtluse neid etappe, kui vestluses osalejatel tekib vajadus mingeid problemaatilisi väljendeid eraldi seletada. Tähenduse seletamisel kasutatakse mitmesuguseid suhtlusstrateegiaid, mille all mõistetakse verbaalseid või mitteverbaalseid vahendeid, mida kõneleja kasutab siis, kui tal on probleeme enda arusaadavaks tegemisega või vestluspartneri öeldu mõist- 
misega. Laialt kasutatavad suhtlusstrateegiad on nt otsene või kaudne abiotsimine, sõnakordused, mõnele muule keelele toetumine, ümberütlemine jm (taksonoomiatest vt nt Dörnyei \& Scott 1997). Tähendusläbirääkimiste käigus lahendavad vestluspartnerid suhtluses tekkinud arusaamisprobleemi ja vestlus saab edasi minna. Evangeline M. Varonis ja Susan M. Gass (1985: 73-78) eristavad tähendusläbirääkimiste ülesehituses kindlaid etappe:

1) põhjustaja (ingl trigger) - kõneleja voor(ud), millest täielikult aru ei saada;

2) osutaja/signaal (ingl indicator) - voor(ud), milles kuulaja väljendab oma mõistmatust;

3) vastus (ingl response) - esimese kõneleja voor, milles ta seletab oma ebaselgeks jäänud väljendit;

4) reaktsioon vastusele (ingl reaction to response) - kuulaja reageering seletusele.

Nende voorude kõrval või sees võib esineda veel lühikesi arusaamist kontrollivaid küsimusi (ingl comprehension check), kuid need kontrollküsimused ega ka kuulaja reaktsioon vastusvoorule ei ole tähendusläbirääkimiste kohustuslik osa, vaid need lihtsalt täiendavad tähendusläbirääkimiste kolmest voorust koosnevat põhistruktuuri (Varonis \& Gass 1985).

Keeleõppijate ja emakeelekõnelejate suulist interaktsiooni on mujal maailmas uuritud juba 1980. aastatest alates. Tähelepanuväärsed on Michael Longi uurimused sisendkeele rollist õppijate ja emakeelekõnelejate interaktsioonis ning tema interaktsiooni hüpotees (Long 1983, 1996). Interaktsioonilist lähenemisviisi teise keele omandamise uurimisel on erinevate sihtkeelte puhul rakendanud ka nt S. M. Gass ja E. M. Varonis (1994; Gass 2006), Alison Mackey (1999), Catherine E. Brouwer (2003), Salla Kurhila (2006) jpt. Tähendusläbirääkimisi ja nende mõju keeleomandamisele on uurinud nt E. M. Varonis ja S. M. Gass (1985), John Bitchener (2004), Minna Suni (2008) jt. Eesti keele õppijate ja emakeelekõnelejate suulist suhtlust on seni uuritud 
väga vähe. Mõningast uurimishuvi on pakkunud suhtlusstrateegiad, eriti nende liigitamise seisukohast (Hennoste \& Vihalemm 1999; Kikerpill \& Pool 2002), uuritud on 12-14aastaste vene noorte toimetulekut spontaanses argivestluses eesti eakaaslastega (Hennoste \& Vihalemm 1998), samuti on viidud läbi üks pikiuurimus keeleõppijate suhtlusstrateegiate muutumisest aastase perioodi jooksul (Kikerpill \& Pool 2003). Tähendusläbirääkimisi eesti keele õppijate ja emakeelekõnelejate interaktsioonis ei ole siinkirjutajale teadaolevalt seni uurimustes käsitletud.

\section{Uurimuse materjal, informandid ja uurimisküsimused}

Käesolev artikkel on esimene osa algajate eesti keele õppijate ja emakeelekõnelejate suulist interaktsiooni käsitlevast pikiuurimusest, mille tarbeks on salvestatud viie täiskasvanud eesti keelt teise keelena õppija vaba vestlust emakeelekõnelejatega ühe õppeaasta jooksul. Nelja õppijaga on läbi viidud neli vestlust, ühe, Eestist varem lahkuma pidanud õppijaga kaks vestlust, vestluste vahe on 6-7 nädalat. Uurimisperioodiks oleva õppeaasta jooksul õppisid kõik informandid eesti keelt ülikoolis intensiivkursusel (16 akadeemilist tundi nädalas), enne õppima asumist ei olnud nad Eestis elanud, väheseid kokkupuuteid eesti keelega oli olnud ainult ühel informandil. Kõik vestlused viidi läbi paarides, üheks vestlejaks eesti keele õppija, teiseks paariliseks eesti keelt emakeelena kõneleja. Emakeelseid kõnelejaid osales uurimuses kokku kolm, neist üks vestles kolme informandiga, ülejäänud kaks kumbki ühe informandiga. Vestlused salvestati digitaalse diktofoniga, videosalvestusi selle uurimuse jaoks ei tehtud. Kõigi vestluste keskmine pikkus on 20 minutit.

Käesolevas artiklis käsitletakse ainult esimese lindistuse materjali. Salvestused on tehtud 2010. aasta oktoobris, kui informandid olid viibinud Eestis 6-7 nädalat ja õppinud eesti keelt ligikaudu 100 akadeemilist tundi. Informantideks on (kõigi nimed muudetud): 
1) Alla (emakeel vene, ühine keel L1-kõnelejaga vene keel) ${ }^{1}$;

2) Katja (emakeel udmurdi, ühised keeled L1-kõnelejaga vene ja soome keel);

3) Nadja (emakeel udmurdi, ühised keeled L1-kõnelejaga vene ja soome keel);

4) Maria (emakeel rumeenia, ühine keel L1-kõnelejaga inglise keel);

5) Lilian (emakeel inglise, ühine keel L1-kõnelejaga inglise keel).

Eestikeelsed vestluspartnerid on Liia, Anne ja Riina (nimed muudetud). Kõigil kolmel emakeelsel kõnelejal on eesti keele kui teise keele õpetamise kogemus, kuid keegi neist ei olnud vaadeldavate keeleõppijate eesti keele õpetaja. Tegemist oli vaba vestlusega teemadel, mis alla kahe kuu eesti keelt õppinutele jõukohased võisid olla. Kuna õppijad ja eestikeelsed vestlupartnerid varem tuttavad ei olnud, räägiti esimeses vestluses palju iseendast, oma kodust, keeleõppekogemusest ja Eestis õppimisest.

Neljal informandil (Alla, Katja, Nadja ja Maria) puudus varasem kokkupuude eesti keelega täiesti. Teistest erinev keeletaust on Lilianil, kes oli eesti keelt varem mõnevõrra kuulnud oma vanavanematelt, mistõttu oli tal suulisest eesti keelest arusaamine teistest informantidest parem. Kõnepraktika tal aga peaaegu puudus ja ta õppis eesti keelt algajate kursusel nagu muud informandidki. Väliseesti taust mõjutas Liliani lindistuse pikkust: vestlus Liliani ja Anne vahel kestis 40 minutit, kuna Lilianil polnud erilist probleemi lihtsate eestikeelsete lausungite produtseerimisega ega vestluspartneri kõne mõistmisega. Esimese lindistuse tegemise ajal oli Lilianil seega teiste informantide ees eesti keele osas märgatav edumaa. Liliani kaasamine uurimusse on seotud asjaoluga, et tegemist on pikiuurimusega, millest siinses artiklis käsitletakse ainult esimese lindistuse materjali. Uurimuse järgmistes etappides saab

\footnotetext{
$1 \quad$ L1 - esimene keel, kõneleja emakeel. L1-kõnelejateks nimetatakse selles artiklis keeleõppijate eestlastest vestluspartnereid. L2 - teine keel, keelekeskkonnas omandatav keel, selles uurimuses eesti keel. L2-kõnelejateks nimetatakse selles uurimuses keeleõppijatest informante.
} 
vaadelda muutusi kõigi informantidega peetud vestlustes ning siis on ka näha, kas ja millal teised õppijad Lilianile järele jõuavad ning kas Liliani enda vestluskäitumine aastase perioodi jooksul muutub. Ülejäänud nelja õppija lindistused on umbes 20 minuti pikkused. Katja ja Nadja olid varem õppinud soome keelt, mis neid esimese lindistuse läbiviimise perioodil eesti keele rääkimisel üsna palju segas, kuid samas pakkus ka võimalusi abiotsimiseks.

Emakeelekõneleja ja keeleõppija suhtlus on oma olemuselt alati mingil määral ebavõrdne, kuna õppija keelelised ressursid on paratamatult piiratumad. Ka emakeelekõnelejate keeleõpetaja taust võib vestluse kulgemises rolli mängida. Uurimisküsimuste püstitamisel ja materjali analüüsil on sellega arvestatud.

Artikli eesmärgiks on leida vastused järgmistele uurimisküsimustele:

1) Kas algajate eesti keele õppijate ja emakeelekõnelejate suulises interaktsioonis tuleb ette tähendusläbirääkimistena käsitatavaid olukordi?

2) Kui tähendusläbirääkimisi esineb, siis kas neid põhjustav probleem paikneb peamiselt õppija või emakeelekõneleja voorus?

3) Missuguste suhtlusstrateegiate abil tähendusläbirääkimised lahendatakse?

4) Missugustes olukordades tähendusläbirääkimisi ei teki ja mis põhjustel? Kuidas mõjutab interaktsiooni eestikeelsete vestluspartnerite keeleõpetaja taust?

5) Kas suulises interaktsioonis osalejate strateegiad on sarnased või esineb individuaalseid erinevusi (seda nii L1- kui ka L2-kõnelejatel)? 


\section{Tähendusläbirääkimised ja vestlust toetavad strateegiad suulises interaktsioonis}

\subsection{Probleem L1-kõneleja tekstis}

Siinses artiklis käsitletavas esimeste lindistuste materjalis oli tähendusläbirääkimistena käsitletavate vestlusolukordade põhjuseks enamjaolt see, et õppija ei saanud aru emakeelekõneleja lausungist ning väljendas oma mõistmatust. Tuleb arvestada, et lindistuse läbiviimise hetkeks olid informandid eesti keelt õppinud alla kahe kuu ning selles etapis on ka tuttavatel teemadel rääkimisel arusaamisraskused täiesti ootuspärased, eriti võõra vestluspartneriga vestlemise puhul. Arusaamisraskustest märku andmise strateegiad olid informantidel esimesel vestlusel sarnased: kuna keeleoskus ei võimaldanud mõistmatust veel eesti keeles verbaalselt väljendada, kasutasid informandid mitteverbaalseid suhtlusstrateegiaid (küsiv vaikus, üneemid) või muule ühisele keelele toetumise strateegiat ${ }^{2}$.

(1) Liia: Eestis saab veel suusatada ja uisutada talvel, Lõunakeskuses näiteks saab uisutada, kas te olete käinud?

Katja: ((küsiv vaikus))

Liia: uisutada? katatsja na konkahh?

Katja: aa (...) ei, ei veel.

Liia: see on seal kaugel linna teises otsas seal on jäähall, sinna saab minna.

Katja: jaa ma olen käinud Lõunakeskuses, aga ei uis-

Liia: uisutamas

Katja: ei uisutamas jah.

Näites (1) on tähendusläbirääkimise põhjustajaks Liia voorus esinev verb uisutada, millest Katja aru ei saa. Mõistmatust väljendab ta vaikimisega, mitte verbaalselt. Liia lahendab probleemi vene keelele üleminekuga. Vestluse selleks etapiks oli tegelikult juba selge, et vestlejate ühine

2 Keelenäidetes kasutatavad transkriptsioonimärgid on toodud artikli lõpus. Näidetes esinevad võõrkeelsed sõnad on kaldkirjas, venekeelsed sõnad esitatakse veneeesti transkriptsioonis (EKK 2007: 82-84). 
keel on lisaks vene keelele ka soome keel, kuid soome keelele üleminekut Liia oma vastusvoorudes kogu vestluse jooksul ei kasuta. Näite (1) lõpus võtab Katja uue verbi uisutama kohe kasutusele, toetudes sisendkeelest saadud uuele infole. Liia strateegia on toetada õppijat, esmalt eestikeelset verbi vene keelde tõlkides, hiljem õiget sõnavormi pakkudes.

M. Longi interaktsioonihüpoteesi kohaselt aitavad tähendusläbirääkimised teise keele omandamisele kaasa (Long 1983, 1996). Hüpoteesi esialgses versioonis pidas Long määravaks just arusaadava sisendkeele kättesaadavust tähendusläbirääkimiste käigus, hilisemas versioonis tõstis ta keskpunkti keeleliste vormide märkamise ja parandamise tähendusläbirääkimiste abil. Näide (1) illustreerib vestlusolukorda, mille puhul mõlemad vestluspartnerid pööravad tähelepanu nii lausungite sisule kui ka vormile. Katja saab esmalt teada talle veel võõra eestikeelse verbi uisutama tähenduse ning kordab Liia voorust kuuldud vormi uisutamas. Selles õppimise etapis ei olnud mas-vormile veel keeletundides erilist tähelepanu pööratud ning võib öelda, et vestluses osalemine pakkus Katjale ka keeleõppevõimalust. mas-vormi kasutamine Liia lausungis Katja jaoks probleemi ei tekitanud, võimalik, et selle vormi funktsiooni mõistmisele aitas kaasa varem õpitud soome keel.

Esimese näitega sarnaneb ka näide (2), mis illustreerib Alla ja Liia vestluses kujunenud tähendusläbirääkimist. Selles näites ei saa Alla aru Liia voorus esinenud sõnast ühiselamu ning reageerib sellele vaikimisega. Ka selles näites lahendab Liia probleemi vestlejate ühisele keelele vene keelele - üle minnes ning Alla väljendab mõistmist, korrates talle pakutud eestikeelset sõna ühiselamus lausungisse sobivas vormis.

(2) Liia: aga te elate ühiselamus?

Alla: ((küsiv vaikus))

Liia: ühiselamu? obštšežitije?

Alla: aa jah, ma elan ühiselamus.

Arusaamisprobleemile osutamine küsiva vaikuse kaudu ei olnud siiski ainus õppijate poolt kasutatud suhtlusstrateegia. Tuli ette ka otseseid küsimusi, kuid siin vaadeldavates esimestes vestlustes ei olnud õppijate 
keeleoskus veel eesti keeles küsimuste produtseerimiseks piisav ning raskuste korral esitati küsimus muus vestlejatele ühises keeles. Näites (3) esitab Nadja täpsustava küsimuse vene keeles.

(3) Liia: et millal sa tulid Tartusse?

Nadja: kogda?

Liia: $\mathrm{mhmh}$

Nadja: me tulin (...) augustis, augusti lõpus.

Näites (3) on tähendusläbirääkimise põhjustaja Liia voorus kasutatud küsimus millal?, mille tähenduse õigesti mõistmises Nadja kindel ei ole. Arusaamisprobleemi signaaliks on Nadja venekeelne küsimus kogda? (ee millal?). Liia saab vene keelest aru, vastab nõusolekut märkiva mõminaga ja vestlus saab edasi minna.

Näites (4) esitatakse lõik Katja ja Liia vestlusest, milles otsene tähendusläbirääkimine on ära toodud rasvases kirjas.

(4) Liia: kas teil on koduigatsus ka?

Katja: no (.) mõnikord on.

Liia: mida te siis teete?

Katja: ee:?

Liia: mida te teete? (.) kui on koduigatsus?

Katja: aa (.) ma helistan koju, vanemale (...) räägin (...) kui kui see kojuiga- igats-

Liia: igatsus

Katja: ma räägin oma sõbraga (...) Tartus on palju udmurdid.

Näites (4) ei teki õppijal probleemi sõna koduigatsus mõistmisel, tähendusläbirääkimine algab hoopis Liia küsimusest mida te siis teete? Katja signaaliks, et ta ei saa küsimusest aru, on küsiva intonatsiooniga üneem $e e:$ Tegelikult ei ole siin asi selles, et Katja ei mõistaks mõne Liia küsimuses sisalduva sõna tähendust, probleemiks on küsimuse kui terviku seostamine eelneva vestlusega. Kathryn A. Rulon ja Jan McCreary (1986) on suulise interaktsiooni protsesse, kus läbirääkimiste põhjustajaks on eelneva vestlusosa sisu, nimetanud sisuläbirääkimisteks (ingl negotiation of content). Näites (4) ongi tegemist olukorraga, kus õppija ei saa 
alguses aru, mida peaks küsimusele vastama ehk siis ei oska küsimust seostada vestlusteemaga. Liia lahendab olukorra küsimuse kordamisega eesti keeles ning sellele täpsustava lisaküsimuse lisamisega ( $k u i$ on koduigatsus?). Vestlejate muudele ühistele keeltele selles katkendis ei toetuta. Sõna koduigatsus tähendus on Katjale retseptiivselt arusaadav, katkendi lõpuosas püüab ta seda ka ise produtseerida, pakkudes eri variante, kuni Liia õige vormi kätte annab.

Näide (5) illustreerib Maria ja Riina vestluses esinenud tähendusläbirääkimist, milles Maria väljendab oma mittemõistmist mitteverbaalselt ehk lihtsalt vaikimisega. See on märguandeks Riinale, kes kordab oma küsimust eesti keeles. Kordamine lahendab arusaamisprobleemi ning vestlus jätkub. Verbaalseid suhtlusstrateegiaid Maria esimeses vestluses mõistmisprobleemide tekkimisel ei rakendanud.

(5) Riina: kui vana sa oled praegu?

Maria: ((küsiv vaikus))

Riina: kui vana sa oled praegu?

Maria: ma vana (...) eem, ee: kakskümmend üks

Uurimuse viies informant Lilian oli ainuke, kes oli varem eesti keelega oma vanavanemate kaudu natuke kokku puutunud. Seetõttu oli tal lihtsama sõnavaraga eestikeelses vestluses osalemine teistest informantidest tunduvalt kergem, mis avaldub muu hulgas ka selles, et tema ja Anne esimeses vestluses ei esinenud ühtki sellist tähendusläbirääkimiste juhtumit, mille puhul oleks Lilianil tekkinud raskusi Anne kõne mõistmisega.

\subsection{Probleem L2-kõneleja tekstis}

Esimeste lindistuste materjalis oli kokku ainult kolm näidet, kus emakeelekõneleja ei saa õppija öeldust aru ja küsib selgitusi. Seejuures ei ole selgituste küsimise põhjuseks otseselt see, et õppija produtseeritud eestikeelne väljend oleks arusaamatu, põhjuseks on pigem kahtlemine öeldu sisus või hoopis püüd õppijat väljendumisel toetada.

Näites (6) kahtleb L1-kõneleja keeleõppija poolt kasutatud määrsõnas vähem. Seejuures ei ole probleemiks sõna tähendusest arusaa- 
mine, vaid tegemist on keelevälise sisulise küsimusega. Seda näidet võiks pidada eespool mainitud sisuläbirääkimiste hulka kuuluvaks. Liia tahab täpsustada, kas Nadja mõtles tõesti vähem, mitte ei ajanud määrsõnu vähem ja rohkem omavahel segamini. Vestlusest selgub, et nii oligi.

(6) Liia: et selles külas, kust sa oled pärit, (.) et seal räägitakse udmurdi keelt?

Nadja: jah (...) no udmurdi see külas asuvad udmurtlased, tatarilased ja venelased (...) no udmurti vähem.

Liia: vähem?

Nadja: ei vähem (...) rohkem

Liia: rohkem, (.) nii et külas räg̈gitakse rohkem udmurdi keelt

Nadja: $\mathrm{mhmh}, \mathrm{mhmh}$

Näitele (7) eelnevas vestluseosas on olnud juttu sellest, et Maria käib raamatukogus õppimas ja lugemas iga päev. Tähendusläbirääkimisena käsitatav vestluslõik on toodud rasvases kirjas.

(7) Riina: iga päev, sulle meeldib õppida?

Maria: ((naer)) jaa, aga ma pean õppima (...) ee:

Riina: mhmh, sa pead õppima jah.

Maria: to have a good carrier

Riina: kuidas?

Maria: to have a good carrier

Riina: jaa jaa, et saada head karjääri, (.) et teha head karjääri, hea karjäär

Maria: jaa, kui ma opin eesti keelt (...) ee: millal läheb lähen ee: tagasi Rumeenias

Riina: jaa

Maria: ee: võimalik (.) ee: mul on hea ee: (...) amet

Riina: jaa, jaa

Näites (7) ütleb Maria, et ta peab õppima ning Riina arvab, et saab sellest lausungist õigesti aru, väljendades oma mõistmist. Maria järgmisest, ingliskeelsest voorust aga selgub, mida ta tegelikult lausungiga ma pean óppima öelda tahtis: nimelt ei pea ta õppima mitte lihtsalt oma eesti keele kursuse jaoks, vaid selleks, et teha tulevikus eesti keele oskuse abil head 
karjääri. Riinale tuleb Maria ingliskeelne lausung ootamatuna ning ta reageerib sellele täpsustava küsimusega kuidas?, algatades sellega tähendusläbirääkimise. Vastusvoorus kordab Maria inglise keeles öeldut. Riina reageerib lausungi eesti keelde tõlkimisega, esmalt otsetõlkega et saada head karjääri, seejärel parandab lausungi eesti keele pärasemaks et teha head karjääri ning pakub Mariale veel lausungi mõistmiseks väljendi hea karjäär kordust. Maria ei võta pakutud väljendit vastu, vaid jätkab teemat põhjendusega, miks eesti keele õppimine talle kasulik on. Riina kordusi sisaldav vastusvoor on näide sellest, kuidas L1-kõnelejad vestluses keeleõppijatega oma lausungeid modifitseerivad, et oma kõnet õppijale arusaadavamaks teha. Kordused kuuluvad L1-kõnelejate universaalsete strateegiate ja taktikate hulka, mille abil vestluses esinevaid probleeme nii välditakse kui ka parandatakse (Long 1983: 132).

(8) Riina: kas ta teadis Eestit? (.) sinu õpetaja teadis Eestit?

Maria: jah (.) minu õpetaja ee: oli

Riina: oli siin?

Maria: jah, oli siin (...) mm (...) tema on opin ee (...)

Riina: Eestis?

Maria: Baltic ee:

Riina: Baltic Studies?

Maria: jaa, Baltic Studies.

Näites (8) püüab Riina aimata Maria kavatsusi, pakkudes talle järjest erinevaid võimalusi lausungite lõpetamiseks. Tegemist ei ole otseselt mõistmatuse väljendamisega, vaid toetuse pakkumisega - Maria räägib aeglaselt, valib sõnu ning Riina püüab arvata, mida ta tahab öelda. Näidet võib pidada tervikuna üheks pikaks tähendusläbirääkimiseks, mille käigus selgitab Riina välja, et Maria õpetaja on olnud Eestis ja õppinud Balti õpingute programmis (ingl Baltic Studies). Signaaliks, et Maria lausungis on midagi ebaselge, on kõigil kolmel juhul täpsustav küsimus: oli siin?, Eestis?, Baltic Studies?. Esimene ja kolmas küsimus said vastuse, küsimus Eestis? jäi aga vastuseta, selle asemel täpsustas Maria õppeprogrammi, milles tema õpetaja osales. Riina küsimus Eestis? on ajendatud sellest, et Maria kõne on aeglane ja selles esineb väga palju täiteüneeme 
ee:, millest üht Riina ekslikult pidas toponüümi Eesti algusvokaaliks. Ühisele arusaamisele jõudmine (õppeprogrammi Baltic Studies nimetamine ja äratundmine) oli võimalik vestluspartnerite ühiste keeleväliste taustateadmiste tõttu: kuna õppija L1-kõnelejast vestluspartner Riina on ülikoolieluga kursis, oskas ta Maria lausungile sobivat lõpetust pakkuda. Riina strateegiaks kogu vestluse jooksul on õppija toetamine, mistõttu ta ei jää pikalt lausungite lõpetusi ootama, vaid pakub omalt poolt midagi välja, mis enamasti ka Maria poolt vastuvõttu leiab.

Õppijate voorust põhjustatud tähendusläbirääkimiste vähesuse üheks põhjuseks võib pidada L1-kõnelejatest vestluspartnerite kogemust eesti keele õppijatega suhtlemisel, samuti ühiste keeleväliste taustateadmiste olemasolu. Järgmistes alaosades kirjeldatakse vestlusolukordi, milles tähendusläbirääkimised oleksid olnud võimalikud, kuid neid ei tekkinud vestluses osalejate poolt rakendatud vestlusstrateegiate tõttu.

\section{3. Õppijal on väljendumisprobleem, mille lahendab L1-kõneleja}

Esimeste lindistuste materjalis esines rohkesti vestlusolukordi, kus õppijal on raskusi alustatud lausungi lõpetamisega. Selles alajaotises analüüsitakse näiteid, milles klassikalisi tähendusläbirääkimisi ei teki, kuna emakeelekõnelejatest vestluspartnerid mõistavad õppijate lausungeid poolelt sõnalt ning lõpetavad need ilma täpsustavate küsimusteta. L1-kõnelejatel ei ole probleemi õppijate kõne mõistmisega, mida näitab ka küsiva intonatsiooni puudumine nende lausungites. Vestluses teisele keelele ei toetuta ja tähendusläbirääkimist ei teki.

Näites (9) saab Riina aru, et Maria räägib ajalooõpetajast. Maria võtab pakutud keelendi vastu ja kordab seda, arusaamisprobleemi kummalgi ei teki. Niisugune õppija sõnade lõpetamine on kõigi kolme uurimuses osalenud emakeelekõneleja ühine strateegia.

(9) Maria: --- tema on õpetaja, ee: ajal-

Riina: ajaloo õpetaja

Maria: ajaloo õpetaja 
Ka näites (10) jääb Maria hätta alustatud sõna lõpetamisega. Riina ei jää Maria variante ootama, vaid lópetab alustatud sõna, mida Maria kohe oma järgmises lausungis kordab. Näites tuleb hästi esile vestluspartnerite mõju üksteise voorudele: Riina pakub pidevalt oma abi, Maria aga püüab sisendkeelest kuuldud uusi eestikeelseid sõnu kohe aktiivselt kasutada.

(10) Riina: sa räägid inglise keeles nendega?

Maria: jaa, inglise keel ja ee: minu tuba on (...) toas on ainult prants-

Riina: prantslane

Maria: prantslane ja sakslane ja hiinlane

Riina: ohhoo väga huvitav

Maria: jaa

Esitatud näites takerdub Maria rahvust näitava tuletusliite kasutamise taha. Kui Riina on õige suuna kätte näidanud, oskab ta analoogiale (ja kindlasti ka keeletundides ópitule) toetudes ise moodustada veel kaks lane-liitelist sõna. Maria lausungist jääb mulje, nagu elaksid nad toas neljakesi. Taustainfot teades võib arvata, et Maria rääkis tegelikult ka naabertoa elanikest, kuid vestluses seda teemat enam ei täpsustata, vaid minnakse üle uuele teemale. Teemade kiire vaheldumine ja ühe teema käsitlemise lühidus on M. Longi (1983) järgi emakeelekõnelejate strateegia keeleõppijate kommunikatiivse koorma vähendamiseks. Siinses artiklis analüüsitavates vestlustes tuleb see strateegia hästi esile L1-kõnelejad ei püüa teemasid jätkata, kui paistab, et õppijatel ei jätku vajalikke keelelisi ressursse või kui mõni teema tundub sisult ebamugavana.

Toanaabritest on juttu ka Anne ja Liliani vestluses (11). Lilian jääb hätta sõna lõpetamisega ja Anne lõpetab selle ise, Lilian nõustub pakutud variandiga ning kordab seda.

(11) Anne: elad nagu üksinda toas või?

Lilian: ei mul on üks tub-

Anne: toakaaslane

Lilian: toakaaslane jah 
Ka kolmas L1-kõneleja Liia kasutab samasugust õppijat toetavat strateegiat ja pakub õppija kavatsusi aimates sobivaid sõnavariante välja (näide 12).

(12) Liia: kas need on kurvad laulud või rõõmsad laulud? Nadja: kaks laulud on rõõmsad ja kaks laulud on kuLiia: kurvad Nadja: kurvad jah

Näites (12) on Nadjale sisendkeeles kuuldud sõnade kurvad ja rõõmsad tähendus arusaadav ning ta võtab need oma voorus kohe aktiivselt tarvitusele. Kuna produtseeritav lausung on algaja keeleõppija jaoks pikk, ununeb vahepeal Liia lausungis esimesena nimetatud adjektiivi kurvad terviklik kuju, Liia lõpetab poolelijäänud sõna, mida Nadja omakorda kordab.

Selles alajaotises esitatud vestlusnäiteid iseloomustab emakeelekõnelejate püüd vestlust edasi aidata. Tegelikult ei ole võimalik kindlalt öelda, kas L2-kõnelejad oleksid osanud ka ise alustatud sõnad lõpetada, kui neile oleks rohkem aega jäetud. Eesti keele õppijate ja keeleõpetajatest emakeelekõnelejate suhtlusstrateegiaid uurinud Tiina Kikerpill ja Raili Pool (2002) kirjeldavad samasuguseid vestlusolukordi, kus õppija jätab sõna pooleli ning L1-kõneleja lõpetab selle ise. T. Kikerpilli ja R. Pooli arvates kiirustasid nende uurimuse L1-kõnelejad liialt, andmata sageli õppijatele piisavalt aega ning käitusid sel viisil alateadlikult pigem õpetajatena kui võrdsete vestluspartneritena (samas). Siinse artikli informantide eesti keele oskus oli väiksem kui eelmainitud uurimuses ning abivajadus vastavalt suurem. Õppijate ühiseks strateegiaks on pakutud sõnade vahetu kordamine. Kordused on igasuguse interaktsiooni loomulik osa. Just korduste kaudu toimub õppijate ja emakeelekõnelejate vestluses keeleliste ressursside jagamine, mis omakorda muudab kordamise teise keele omandamise protsessi osaks (Suni 2008). 


\section{4. Õppija väljendumisprobleemi lahendamine teisele keelele toetumisega}

Siinse uurimuse informantide ühiseks strateegiaks on sagedane üleminek mõnele muule ühisele keelele. Vestluse loomulikkuse huvides ei hakanud ükski vestlustes osalenud emakeelekõneleja teesklema, et ta teises keeles öeldud sõnadest või pikematestki lausungitest aru ei saa. Võimaluse korral pakkusid nad omalt poolt välja teises keeles öeldud sõnade eestikeelsed vasted, hoides vestlust sel viisil eestikeelses raamistikus. Sellesse alaosasse on koondatud näited, milles tähendusest arusaamise probleemi kummalgi vestluspartneril ei teki. Probleemiks ei ole siin mitte öeldust arusaamine, vaid õppijatel on raskusi oma mõtte eesti keeles edasiandmisega, mistõttu nad väljendavad ennast osaliselt mõnes muus vestlejatele ühises keeles. Teisisõnu, L1-kõneleja saab aru ja tähendusläbirääkimist ei teki.

Katja ja Nadja olid hariduse saanud vene keeles ning olid varem õppinud ka soome keelt. Nende vestlustes Liiaga tuli kiiresti välja ka Liia soome ja vene keele oskus. Seetõttu kasutasid mõlemad õppijad esimeses vestluses väljendusraskuste korral abivahendina nii soome kui ka vene keelt. Soomekeelsed sõnad lipsasid nende jutu sisse mõnikord ka ebateadlikult: kuna esimese vestluse toimumise hetkeks ei olnud eesti ja soome keele süsteemid nende keeleteadmistes veel selgesti eristatavad, pidasid nad vahetevahel soomekeelseid sõnu eestikeelseteks. Näites (13) kasutab Nadja nii soome kui ka vene keelt - soome keeles ütleb tõlkimist vajava sõna (ensin, ee alguses), vene keeles küsib abi (kak skazat?, ee kuidas öelda?).

(13) Nadja: no (...) ensin (...) kak skazat?

Liia: alguses

Nadja: ajaa, alguses mulle ei meeldi Tartu

Näites (14) tahab Nadja rääkida lauluhäälest, kuid ei tea eestikeelset sõna hääl, öeldes selle soomekeelse vaste küsiva intonatsiooniga (ääni?). Liia annab eestikeelse variandi, mille Nadja kohe kasutusse võtab. 
(14) Nadja: no mul ei ole kaunis (...) ääni?

Liia: hääl

Nadja: hääl jah

Samas näites kasutab Nadja adjektiivi kaunis, mis on eesti ja soome keeles samakujulisena olemas. Tõenäoline on siiski, et ta kasutab siin soomekeelset sõna, seda ise eestikeelseks pidades. Liia ei paku omalt poolt välja tavalist eesti adjektiivi ilus, kuna Nadja seda ei küsi ning arusaamisprobleemi ei teki.

Näites (15) kasutab soomekeelset sõna Katja. Kuna ta kasutab soomekeelset tüve koos eesti inessiivi lõpuga (tiedekunnas) ja tema lausungis puudub küsiv intonatsioon ning eksplitsiitne abiotsimine, võib arvata, et ta peab sõnakuju eestikeelseks. Liia soovib talle eestikeelse sõna kätte anda, tõlkides sõna eesti keelde (teaduskonnas), mida Katja kohe järgmises voorus kordab.

(15) Liia: aga mida sa Tartus teed?

Katja: Tartus (...) praegu ma õpin eesti keelt, (...) ja (...) pärast ma õpin tiedo- tiedekunnas.

Liia: teaduskonnas

Katja: teaduskonnas

Vene keelele toetumine on Katjal ja Nadjal alati teadlik ning nad ootavad vestluspartnerilt eestikeelse vaste pakkumist. Näites (16) räägivad Katja ja Liia vanadest lauludest ning Katja saab teada, et venekeelse sõna kuplet eesti vaste on salm.

(16) Liia: millest need vanad laulud räägivad, kas armastusest või?

Katja: jaa (...) armastusest üks laul on (...) see esimene (...) kuplet?

Liia: salm

Katja: salm, (.) sina oled külaline, mina olen külaline (...) sa tahad oma laulud (...) üks inimene an- kinkida

Kõige rohkem toetus muule keelele Maria, kelle ühiseks keeleks Riinaga oli inglise keel. Maria tunnistas vestluse käigus, et eesti keele õppimine on tema jaoks raske ning et see on väga erinev tema emakeelest rumeenia keelest. Sellest hoolimata tundis ta eesti keele vastu suurt huvi, soovides 
oma tuleviku eesti keele oskusega siduda. Näites (17) esitatakse pikem vestluslõik, milles Maria saab inglise keelele toetudes teada uue eestikeelse sõna territoorium. Näide on tähelepanuväärne seetõttu, et Maria mitte lihtsalt ei korda Riina pakutud üksiksõna, vaid produtseerib kohe kolmesõnalise lausungi poole territoorium Prantsusemaalt, mis on tema selle hetke keeleoskust arvestades oluline samm edasi. Riina strateegia on kogu vestluse jooksul pakkuda välja korrektseid eestikeelseid lausungeid, nii ka selle näite lõpus, kuid Maria parandatud varianti enam vastu ei võta, vaid lihtsalt väljendab oma nõustumist.

(17) Riina: Rumeenia on väga suur maa.

Maria: jaa jaa

Riina: väga suur maa

Maria: suur maa (...) pool (...) ou (...) mm: I don't know how to say

Riina: mida sa tahad öelda? proovi ütelda

Maria: ee: area, territory

Riina: territoorium

Maria: poole territoorium Prantsusemaalt

Riina: mhmh, nagu pool Prantsusmaa territooriumi.

Maria: jaa

Eesti juurtega Lilian kasutab vestluses Annega leksikaalsete lünkade korral ingliskeelseid sõnu ja väljendeid, mõnikord Annelt eestikeelset vastet oodates ja seda kohe ise kasutades (18), mõnikord mitte (19).

(18) Lilian: --- ja tema tuli tagasi ja teeb tema masters

Anne: magistrit

Lilian: magistrit jah

(19) Lilian: --- seal on eesti selts või community

Anne: jah, kogukond

Lilian: kogukond (.) see on natukene (...) competition kui sa teed rohkem eesti asjad ---

Liliani eesti keele oskus on teistest selle uurimuse informantidest parem, mistõttu tal Anne eestikeelsete voorude mõistmisega probleeme ei ole. Raskused tekivad tal peamiselt siis, kui ta ingliskeelsete sõnade eesti- 
keelseid vasteid ei tea. Liliani voorud on kohati väga pikad ning Anne strateegiaks on sekkuda ainult nendel juhtudel, kui Lilian ise peatub. Peatumine on Annele märguandeks, et ta võiks kas ise midagi öelda või Liliani öeldut korrigeerida. Näites (18) peatub Lilian pärast ingliskeelse sõna masters (ee magistritöö) lausumist, mis on Annele märguandeks, et selle võiks eestikeelsena välja pakkuda. Lilian võtab abi vastu ja kordab eestikeelset varianti magistrit. Näites (19) kordub sama muster ingliskeelse sõnaga community, millele Anne pakub eesti vasteks kogukond, mida Lilian kordab. Samas voorus kasutab Lilian sujuvalt ingliskeelset sõna competition (ee võistlus), kuid ei peata oma vooru eestikeelse vaste ootamiseks. Anne ei katkesta ise niisugustel juhtudel sõna tõlkimiseks vestlust, tõenäoliselt saab ta ingliskeelsest sõnast aru ning vestlus ei ole sisuliselt takistatud.

Alla ja Liia vestluse muu ühine keel on vene keel, millele Alla esimese lindistuse ajal vahetevahel toetub. Alla strateegia on öelda vajalik sõna vene keeles ning oodata Liia poolt pakutavat tõlget eesti keelde. Sarnaselt teiste informantidega on Alla jaoks oluline vestluspartneri poolt pakutud eestikeelseid sõnu kohe järele korrata (20).

(20) Alla: mulle meeldib õpib jazõki

Liia: keeled

Alla: keeled jah

Muude ühiste keelte olemasolu aitab ühelt poolt vestlust edasi, kuna arusaamisprobleeme ei teki. Teisalt on muule keelele toetumine õppijate jaoks mugav suhtlusstrateegia, mis võimaldab soovitud mõtet edasi anda ilma nõudlikumate, puhtalt sihtkeele ressursside kasutamist eeldavate strateegiate (nt ümberütlemine) rakendamiseta.

\subsection{L1-kõnelejate tähendusläbirääkimisi ennetavad strateegiad}

Tähendusläbirääkimise vallandab vestlusolukord, kus üks vestlejatest ei saa täielikult aru kaasvestleja voorust ning väljendab oma mõistmatust kas verbaalselt või mitteverbaalselt. Emakeelekõnelejad rakendavad vestluses keeleõppijatega aga mitmesuguseid strateegiaid, mille abil nad 
püüavad ennast keeleõppijale võimalikult arusaadavaks teha ja mõistmisprobleeme vältida. Välismaalastega kõneldavat keelekuju nimetatakse ingliskeelse terminiga foreigner talk, mille iseloomulikeks joonteks on aeglane tempo, selge hääldus, lühikesed ja lihtsad väljendid, kanooniline sõnajärg, idiomaatiliste väljendite vähesus jne (Ferguson 1975; Larsen-Freeman \& Long 1991: 125-126). Sellega sarnaneb ka võõrkeeletundides õpetaja poolt õpilastele suunatud kõne ehk õpetajakõne (ingl teacher talk), mida on uuritud muu hulgas ka soome keele osas ja leitud, et õpetajakõnes esineb tunduvalt vähem kõnekeelele omaseid jooni kui emakeelsetele soome õpilastele suunatud kõnes (Storhammar 1994). Eesti keele osas ei ole välismaalastele suunatud kõne ega õpetajakõne eripära käsitlevaid uurimusi seni avaldatud. Siinse uurimuse eestikeelsetest osalejatest võib õpetajakõnele omaseid jooni leida eelkõige Liia ja Riina tekstist. Anne vestlus Lilianiga oli mõneti erinev: kuna Lilianil arusaamisprobleeme ei olnud, ei püüdnud Anne oma kõnet modifitseerida. M. Long (1983) pakub välja järgmised võimalused, kuidas emakeelekõneleja saab interaktsioonis võimalikke suhtlusprobleeme vältida: valikküsimuste esitamine, arusaadavate ja õppijat huvitavate vestlusteemade valimine, teemade sobival ajal vahetamine ja teemavahetusest märkuandmine, arusaamise kontrollimine. Niisuguseid näiteid esines ka Liia ja Riina kõnes.

Siinse uurimuse materjalis oli Liia ja Riina ühine strateegia vestluspartnerile esitatud küsimuste kordamine ja parafraseerimine. Nii anti keeleõppijale rohkem aega öeldust arusaamiseks ning välditi nii mitmelgi juhul arusaamisprobleemi tekkimist (21-24).

(21) Liia: mitu aastat sa õppisid soome keelt siis, mitu aastat? Katja: viis aastat

(22) Liia: millega te reisite tavaliselt, kas rongiga või lennukiga? Nadja: rongiga

(23) Riina: mitu aastat sa juba õpid? mitu aastat, kaks aastat, kolm aastat? Maria: ee: see on minu kolm aastat.

Riina: see on sinu kolmas aasta praegu.

Maria: $\mathrm{mhmh}$ 
(24) Riina: --- kas sul on oma arvuti, kas sul on arvuti, kompuuter? Maria: ei (.) ma mul ei ole

Näites (21) kordab Liia küsimust mitu aastat? ning küsimus on Katjale arusaadav ilma vastusevariantide väljapakkumiseta. Näites (22) pakub Liia välja omapoolsed vastusevariandid, millest Nadja aru saab ja ühe välja valib. Ei ole teada, kas küsimus oleks ilma vastusvariantideta Nadjale arusaadav olnud. Näitega (21) sarnaneb näide (23), milles Riina peab vajalikuks kordusküsimuses ka omapoolsed vastusevariandid välja pakkuda, millest Maria ühe ka oma voorus välja valib. Riina tunnetab eriti selgelt, et Maria vajab eestikeelse kõne mõistmisel abi ning modifitseerib oma lausungeid emakeelsetest vestlejatest kõige rohkem. Riina strateegia on pakkuda sageli sama küsimuse kordusi, parafraase ning sõnade rahvusvahelisi sünonüüme. Tema vestluskäitumises on tunda keeleõpetaja soovi arvestada õppija keeleoskuse tasemega. Seda illustreerib hästi ka näide (24), milles Riina ei jää esimesele küsimusele kas sul on oma arvuti? reageeringut ootama, vaid kordab kohe sama küsimust ning pakub seejärel veel välja võõrsõnalise sünonüümi kompuuter. Riina pingutused kannavad vilja, Maria saab küsimusest aru ning vestlus saab edasi minna.

Teine Liia ja Riina ühine strateegia õppijate kommunikatiivse koorma vähendamiseks on enda öeldud eestikeelsete sõnade vahetu tõlkimine ühisesse keelde, ilma et sellele eelneks õppijapoolne verbaalne või mitteverbaalne märguanne mõistmisprobleemist (25-27).

(25) Liia: aga udmurdi rahvakalendris, see on natsionalnõi kalendar, selles on mingeid erilisi tähtpäevi?

Nadja: ei, see on sama kui Venemaal.

(26) Riina: aga mida sa teed Tartus tavaliselt, usually, tavaliselt reedel, kas sa magad kaua või käid kinos?

Maria: ma käin raamatukogus.

(27) Riina: kas see on raske? is it difficult?

Maria: jaa (...) see on raske 
Näited illustreerivad vestlusolukordi, milles L1-kõnelejad ennetavad arusaamisprobleemi tekkimist oma lausungite osalise tõlkimisega kas vene keelde (25) või inglise keelde $(26,27)$. Eesti keele kui teise keele õpetajatena oskavad Liia ja Riina sageli arvata, missugused väljendid nende vestlupartneritele eesti keeles arusaamatuks võivad jääda. Omapoolsete tõlkevarintide pakkumisega ennetavad nad toodud näidetes võimalikke mõistmisprobleeme ning õppijate vastusvoorudes ilmneb, et selliselt modifitseeritud küsimused on arusaadavad.

\section{Kokkuvõte}

Artiklis vaatluse all olnud algajate eesti keele õppijate ja emakeelekõnelejate suulist suhtlust võib täie õigusega nimetada interaktiivseks - õppijad toetuvad emakeelekõnelejate voorudele, võtavad kuuldud keelendeid vestluses vahetult tarvitusele ja kasutavad oma keelelisi ressursse maksimaalselt ära. Emakeelekõnelejad omakorda püüavad aimata õppijate kavatsusi, toetavad nende alustatud lausungeid omapoolsete täiendustega, kordavad ning parafraseerivad öeldut - teevad kõik, et õppijatel oleks lihtsam nende keelekasutust mõista ja ennast eesti keeles väljendada. Artikli alguses püstitatud uurimisküsimused said materjali analüüsi käigus vastused.

Tähendusläbirääkimistena käsitleti siinses artiklis olukordi, kus ühel vestlejal tekib probleem vestluspartneri lausungi mõistmisega ning ta annab sellest märku kas verbaalsete või mitteverbaalsete suhtlusstrateegiate rakendamisega. Vaadeldud vestlustes olid tähendusläbirääkimiste põhjustajaks peamiselt L1-kõneleja voorud, millest keeleõppijad täielikult või osaliselt aru ei saanud. Kõigi uurimuses osalenud õppijate ühiseks suhtlusstrateegiaks mõistmisprobleemist märkuandmisel oli käsitletud keeleõppeetapil (informandid olid õppinud eesti keelt intensiivselt umbes 100 akadeemilist tundi) kas paus või selgituse küsimine mõnes muus vestlejatele ühises keeles. Paus on mitteverbaalne suhtlusstrateegia, mille põhjuseks võib pidada keeleliste ressursside vähesust otsese küsimuse moodustamiseks. Eestikeelseid märguandeid aru- 
saamisraskuste kohta siinses artiklis analüüsitud esimestes lindistustes ei kasutatud. Emakeelekõnelejad reageerivad nii mitteverbaalsetele kui verbaalsetele signaalidele ning vestlejad lahendavad mõistmisprobleemi korduste, täpsustuste ja tõlkimise kaudu. Emakeelekõnelejatel keeleõppijate kõne mõistmisel probleeme peaaegu ei tekkinud ning väheseid olukordi, kus L1-kõneleja annab märku arusaamisprobleemist, võib nimetada pigem sisu-, mitte tähendusläbirääkimisteks.

Algajatel keeleõppijatel tekkis vestlustes sageli väljendumisraskusi, mille puhul nad kasutasid sarnaseid suhtlusstrateegiaid: kas jätsid alustatud sõna pooleli või toetusid muule ühisele keelele. Selliseid olukordi ei loetud siinses artiklis tähendusläbirääkimisteks, kuna vestluspartnerist arusaamise probleemi L1-kõnelejatel ei tekkinud. Eesti keele kui teise keele õpetajatena oskasid nad õppijate poolelijäänud sõnadele sobivad lõpetused välja pakkuda, samuti said aru muudes keeltes kasutatud sõnadest ja lausungitest. Suulise interaktsiooni oluline osa on kordamine, mida analüüsitud vestlustes kasutasid nii õppijad kuuldud väljendite kinnistamiseks kui L1-kõnelejad õppijate kommunikatiivse koorma vähendamiseks.

Kahe vestlustes osalenud emakeelekõneleja kõne (Liial ja Riinal) on näide nn õpetajakõnest: sõnavara ja grammatiliste struktuuride kasutamisel püütakse arvestada vestluspartneri keeleoskustasemega, korratakse öeldut eesti keeles ja pakutakse tõlget muusse keelde ilma mõistmisprobleemi märguandeta, parafraseeritakse öeldut, teemasid vahetatakse kiiresti. Niisuguste strateegiate kasutamisega ennetavad Liia ja Riina arusaamisprobleemide tekkimist ja tähendusläbirääkimisi nendel juhtudel ei toimu. Anne suhtlusstrateegiad Lilianiga vestlemisel on pisut erinevad Liliani parema eesti keele oskuse tõttu. Anne ei paku ise välja tõlkeid ega sünonüüme, kuna Lilian ei vaja seda, tema kõnetempo on kiire ja voorud pikad. Anne strateegiaks on lasta õppijal nii pikalt eesti keeles rääkida, kui ta soovib ning sekkuda peamiselt siis, kui temalt abi otsitakse või vestluses loomulik paus tekib.

Käesolev artikkel on esimene osa eesti keele õppijate ja emakeelekõnelejate suulist interaktsiooni käsitlevast pikiuurimusest. Uurimuse 
järgmistes etappides saab juba vaadelda õppijate keeleoskuse kasvades toimuvaid muutusi nii tähendusläbirääkimiste olemuses ja suhtlusstrateegiate rakendamisel kui ka emakeelekõnelejate kõnes täheldatud õpetajakõnele iseloomulikes joontes.

\section{Tänusõnad}

Artikli valmimist on toetanud Alfred Kordelini fond ja Eesti Teadusfondi grant 9300. Tänan südamest kõiki uurimuses osalenud eesti keele õppijaid ja emakeelekõnelejaid.

\section{Transkriptsioonimärgid}

(...) pikem mõõtmata paus

(.) lühem mõõtmata paus

an- pooleli jäänud sõna

ee: häliku venitus

? $\quad$ küsiv intonatsioon

. langev intonatsioon

, poollangev intonatsioon

(( )) litereerija kommentaarid

.. $\quad$ väljajätt

\section{Kirjandus}

Bitchener, John 2004. The relationship between the negotiation of meaning and language learning: a longitudinal study. - Language Awareness 13 (2), 81-95. http://dx.doi.org/10.1080/09658410408667088

Brouwer, Catherine E. 2003. Word searches in NNS-NS interaction: opportunities for language learning? - The Modern Language Journal 87 (4), 534-545. http://dx.doi.org/10.1111/1540-4781.00206

Dörnyei, Zoltan, M.L. Scott 1997. Communication strategies in a second language: definitions and taxonomies. - Language Learning 47 (1), 173-210. http:// dx.doi.org/10.1111/0023-8333.51997005

EKK 2007 = Erelt, Mati, Tiiu Erelt, Kristiina Ross 2007. Eesti keele käsiraamat. Kolmas, täiendatud trükk. Tallinn: Eesti Keele Sihtasutus. 
Ferguson, Charles A. 1975. Toward a characterization of English foreigner talk. Anthropological Linguistics 1, 1-14.

Gass, Susan M. 2006. Input and Interaction. - Catherine J. Doughty, Michael H. Long (Eds.). The Handbook of Second Language Acquisition. Malden: Blackwell Publishing, 224-255.

Gass, Susan M., Evangeline Marlos Varonis 1994. Input, interaction, and second language production. - Studies in Second Language Acquisition 16 (3), 283-302. http://dx.doi.org/10.1017/S0272263100013097

Hennoste, Tiit, Triin Vihalemm 1998. Vene noorte toimetulek spontaanses argivestluses eesti eakaaslastega. - Marju Lauristin, Silvi Vare, Tiia Pedastsaar, Marje Pavelson (Toim.). Mitmekultuuriline Eesti: väljakutse haridusele. Tartu: Tartu Ülikool, 249-273.

Hennoste, Tiit, Triin Vihalemm 1999. Võõrkeele suhtlusstrateegiad. - Akadeemia 8, 1571-1607.

Kikerpill, Tiina, Raili Pool 2002. Soome-ugri üliõpilaste eesti keele suhtlusstrateegiad. - Liina Lindström, Oksana Palikova (Toim.). Emakeel ja teised keeled III. Tartu Ülikooli eesti keele (võõrkeelena) õppetooli toimetised 1. Tartu: Tartu Ülikooli Kirjastus, 81-94.

Kikerpill, Tiina, Raili Pool 2003. Muutused eesti keelt teise keelena kõnelejate suhtlusstrateegiate kasutuses ühe aasta jooksul. - Pirkko Muikku-Werner, Hannu Remes (Toim.). VIRSU. Viro ja suomi: kohdekielet kontrastissa. Lähivertailuja 13. Joensuu: Joensuun yliopisto, 50-60.

Kurhila, Salla 2006. Second Language Interaction. Amsterdam: John Benjamins.

Larsen-Freeman, Diane, Michael H. Long 1991. An Introduction to Second Language Acquisition Research. London and New York: Longman.

Long, Michael H. 1983. Native speaker/non-native speaker conversation and the negotiation of comprehensible input. - Applied Linguistics 4 (2), 126-141. http://dx.doi.org/10.1093/applin/4.2.126

Long, Michael H. 1996. The role of the linguistic environment in second language acquisition. - William C. Ritchie, Tej K. Bhatia (Eds.). Handbook of Language Acquisition. Volume II: Second Language Acquisition. New York: Academic Press, 413-468.

Mackey, Alison 1999. Input, interaction, and second language development. Studies in Second Language Acquisition 21 (4), 557-587.

Philp, Jenefer, Rita Tognini 2009. Language acquisition in foreign language contexts and the differential benefits of interaction. - International Review of Applied Linguistics in Language Teaching 47 (3-4), 245-266. http://dx.doi. org/10.1515/iral.2009.011 
Rulon, Kathryn A., Jan McCreary 1986. Negotiation of content: teacher-fronted and small-group interaction. - Richard R. Day (Ed.). Talking to Learn. Conversation in Second Language Acquisition. Rowley, London, Tokyo: Newbury House Publishers, 182-199.

Storhammar, Marja-Terttu 1994. Me mennään vai me menemme? Joitakin suomalaisten ulkomaalaisopettajien opetuspuheen piirteitä. - Raili Pool, Jüri Valge (Toim.). Emakeel ja teised keeled 8.-10. oktoober 1993. Ettekanded. Tartu: Tartu Ülikooli Kirjastus, 153-161.

Suni, Minna 2008. Toista kieltä vuorovaikutuksessa. Kielellisten resurssien jakaminen toisen kielen omaksumisen alkuvaiheessa. Jyväskylä Studies in Humanities 94. Jyväskylä: Jyväskylän yliopisto.

Varonis, Evangeline Marlos, Susan Gass 1985. Non-native/non-native conversations: A model for negotiation of meaning. - Applied Linguistics 6 (1), 71-90. http://dx.doi.org/10.1093/applin/6.1.71

\section{Raili Pool}

Tartu Ülikooli eesti ja üldkeeleteaduse instituut

Jakobi 2

51004 Tartu, Estonia

raili.pool@ut.ee 


\title{
Negotiations of meaning and strategies to support conversation in interactions between learners and native speakers of Estonian
}

\author{
RAILI POOL \\ University of Tartu
}

This article reports the initial part of a longitudinal study of oral interaction of learners and native speakers of Estonian. The subjects of the study are five adult learners (whose native languages are English, Romanian, Udmurt (Votyak) and Russian) with no previous knowledge of Estonian who during the period of the study participated in an intensive course of Estonian. The study also included three subjects who are native speakers of Estonian and who served as conversation partners for the learners. During the one-year investigation period, several conversations (four in the case of four of the subjects, two in the case of one) with an average duration of 20 minutes were recorded between the learner and a native speaker. All L1 subjects possessed an experience of teaching Estonian as a foreign language but none of them was teaching Estonian to the subject learners. The data for this article were drawn from the first recordings, which were made when the subjects had been in Estonia for 6-7 weeks and had had approximately 100 hours of Estonian classes. The conversations were recorded using a digital dictaphone and represent free-form conversation on everyday subjects.

The purpose of the article is to analyse the negotiation of meanings that took place in the conversations, as well as the communication strategies employed to resolve meaning problems and other strategies which were employed to support the conversation and to pre-empt the need to negotiate meanings. For the purposes of this article, negotiation of meanings means a conversational situation in which one participant finds it difficult to understand an utterance made by the collocutor and communicates this to the collocutor by employing a verbal or non-verbal communication strategy. This is followed by the collocutor's reply which attempts to resolve the difficulty. In the material analysed, the need for negotiations of meaning principally arose from utterances 
or groups of utterances made by L1 speakers which the learner failed to understand completely or in part. At this particular stage of their learning process, a communication strategy common to all learner subjects faced with the need to signal a comprehension difficulty to their collocutor consisted in either pausing or requesting an explanation in another language that they knew the collocutor to speak. The learners' level of competency in Estonian was yet insufficient for them to ask for an explanation in that language. L1 speakers on the other hand had very few problems in understanding the speech of the learners and the few complications that did arise were resolved by means of what should properly be termed as negotiations of content rather than meaning.

In the course of the conversations, learners often experienced difficulties in expressing themselves, which they sought to resolve by interrupting their utterance in the middle of the problem word or switching to another common language. Such situations did not impede comprehension in the conversations, because all L1 speakers were able to propose solutions in the form of endings for problem words or utterances, were able to understand expressions uttered in a different common language and translate these into Estonian where necessary. The speech of two L1 speakers showed features characteristic of 'teacher talk', which they used to pre-empt comprehension problems. These include repetition of Estonian words or utterances, translation of the utterance into another language, as well as offering paraphrases and synonyms.

The analysis of the first recordings reported in this article shows that the involvement of native speakers of Estonian with a specific experience of teaching Estonian as a foreign language as conversation partners of beginner learners of the language appears to have been justified. The native speaker partners were often able to predict the meaning of the learner mid-sentence and were able to adapt their speech to the particular learner's level of competency. In the next stages of the study, the authors will focus on the changes that occur in the nature of negotiations of meaning and on the communication strategies employed as the learners' level of competency increases as well as on the features characteristic to teacher talk in the speech of the L1 collocutors.

Keywords: Estonian as a second language; second language acquisition; interactional analysis; negotiations of meaning; communication strategies; teacher talk; Estonian 